\title{
Performance of Kampung Super chicken and Bangkok chicken first generation (G1) until the age of 12 weeks
}

\author{
Fetty Febriana Rahayu, Depison *, Gushairiyanto \\ Animal Science Study Program, Faculty of Animal Husbandry, Jambi University, Jambi, 36361 \\ *Correspondence: depison.nasution@unja.ac.id
}

Received: June 28 ${ }^{\text {th }}$, 2021; Accepted: November 17th, 2021 ; Published online: November 27th 2021

Abstrak

Tujuan: Tujuan penelitian ini untuk mengetahui Performa Ayam Kampung Super dan ayam Bangkok generasi pertama (G1) sampai umur 12 minggu.

Metode: Materi penelitian ini adalah ayam Kampung Super dan ayam Bangkok G1 dengan sampel masing-masing sebanyak 174 ekor. Penelitian ini menggunakan metode eksperimen. Data yang dihimpun meliputi bobot badan, pertambahan bobot badan, ukuran-ukuran tubuh dan respon seleksi. Data bobot badan, pertambahan bobot badan dan ukuran-ukuran tubuh dianalisis menggunakan uji-t independent, sedangkan Vektor nilai rata-rata ukuran-ukuran tubuh ayam Kampung Super dan ayam Bangkok G1 dianalisis menggunakan uji statistik $T^{2}$-Hotelling. Analisis Komponen Utama digunakan untuk mengidentifikasi penciri bentuk dan ukuran tubuh pada ayam Kampung Super dan ayam Bangkok G1.

Hasil: Hasil penelitian ini menunjukkan bahwa bobot badan, pertambahan bobot badan umur DOC4 minggu, 4-8 minggu, 8-12 minggu dan ukuran-ukuran tubuh ayam Kampung Super G1 berbeda nyata $(\mathrm{P}<0,05)$ lebih tinggi dibandingkan ayam Bangkok G1. Penciri ukuran ayam Kampung Super dan Bangkok G1 yaitu lingkar dada. Penciri bentuk ayam Kampung Super dan ayam Bangkok secara berurutan yaitu panjang sayap dan panjang tubuh bawah. Respon seleksi ayam Kampung Super G1 lebih tinggi dibandingkan dengan respon seleksi ayam Bangkok G1.

Kesimpulan: Performan G1 ayam Kampung Super meliputi bobot badan, pertambahan bobot badan, ukuran-ukuran tubuh lebih tinggi dibanding ayam Bangkok. Nilai respon seleksi G1 ayam Bangkok lebih tinggi dibanding ayam Kampung Super. Pertambahan bobot badan tertinggi ayam Kampung Super G1 dan ayam Bangkok G1 dicapai pada umur 8-12 minggu.

Kata Kunci: ayam Bangkok; ayam Kampung Super; performa; respon seleksi

Abstract

Objective: The purpose of this research was to determine the performance of the first generation (G1) Kampung Super and Bangkok chicken aged 12 weeks.

Methods: The research material were G1 Kampung Super and Bangkok chicken with 174 samples for each strain. This research was using the experimental method. The data collected included body weight, body weight gain, body measurements, and selected responses. The body weight, body weight gain, and body measurements data were analyzed using t-test independent, while the average 
value vector of body measured using $T^{2}$-Hotelling test. Principal Component Analysis ware used to identify the characteristics of body shape and size.

Results: The results of this study showed that body weight, body weight gain of DOC-4 weeks, 4-8 weeks, 8-12 weeks, and body measurements of G1 Kampung Super chickens were real different higher $(\mathrm{P}<0.05)$ than G1 Bangkok. The identifier of the size of the G1 Kampung Super and Bangkok chicken is the chest circumference. The characteristics of the shape G1 Kampung Super chicken is the length of the wings and the G1 Bangkok chicken is the lower body lenght. The selection response of G1 Kampung Super is higher than G1 Bangkok.

Conclusions: The performance of G1 Kampung Super chicken was higher than G1 Bangkok chicken but the selection response value of G1 Bangkok chicken was higher than G1 Kampung Super chicken. The highest body weight gain of G1 Kampung Super and Bangkok chickens was achieved at the age of 8-12 weks.

Keywords: Kampung Super chicken; Bangkok chicken; performance; selection response

\section{INTRODUCTION}

Indonesia is currently still not able to meet all food needs for animal protein sources, so it still needs imports. Indonesia has a wide variety of livestock breeds that have the potential to be developed, including local chickens. Among the many local chickens that have the potential to be developed are Kampung Super chickens and Bangkok chickens. Kampung Super Chicken is the result of a cross between a native chicken and a laying hen. These crossbred chickens have a faster growth rate than Kampung chickens, so they are called Kampung Super chickens. Kampung Super chickens also have high productivity, so Kampung Super chicken cultivation is more profitable because it can be harvested in a shorter time, where Kampung Super chickens can be harvested at the age of 8 weeks [1]. The body weight of kampung Super chickens is higher than the body weight of KUB and Kampung chickens at the age of DOC, 4 weeks and 8 weeks [2]. Bangkok Chicken is the result of a cross between a Malay chicken and a local chicken from Ayutthaya, northern Bangkok, which has been successfully developed as a superior breed, both as laying and broiler chickens as well as fighting chickens. Kampung Super chicken and Bangkok chicken are chickens that are widely developed by the community, but the diversity of Kampung Super chicken and Bangkok chicken is still relatively high. So it is necessary to make a selection on the performance of Kampung Super chickens and Bangkok chickens.
Performance is the productivity ability of an animal, performance can be seen from DOC weight, body weight, body weight gain, and body measurements. DOC weight is the weight of chicks weighed after the feathers are dry. Bodyweight is an indicator that describes the weight of livestock as measured using a scale. Weight gain is the difference between final body weight and initial body weight at a certain time [3] reported that the average body weight gain of super chickens reared intensively for 12 weeks was $1.113 \mathrm{~g} / \mathrm{head}$. Body measurements are a collection of quantitative data that can be used to increase livestock productivity. Body sizes are factors that need to be discussed to determine bone growth and the body structure of chickens. Body size has a close relationship with bodyweight [4].

Until now, data regarding hatching weight, bodyweight, body weight gain, and body measurements on G1 Kampung Super and Bangkok chickens are not widely known. For this reason, it is necessary to research the performance of Kampung Super chickens and Bangkok chickens of the first generation (G1) until the age of 12 weeks.

\section{MATERIALS AND METHODS}

\section{Materials}

This study was conducted at Jambi University's Farm Faculty of Animal Science from November 27, 2020 to March 27, 2021. This study used 174 Kampung Super chickens and 174 Bangkok chickens obtained from selected elders. An incubator manual with 
a capacity of 200 is used, as well as stationery, cable ties, digital calipers, digital scales with a capacity of $3000 \mathrm{~g}$ and an accuracy of $0.1 \mathrm{~g}$, digital cameras, measuring tapes, incandescent lamps, feed and drinking containers, The feed used is Japfa Comfeed production with BR1 Energy Composition (kcal/kg): 4,100, Protein (\%):21, Fat (\%):3 - 7, Calcium (\%):0.9 - 1.1, Phosphorus (\%): 0.6 - 0.9, and BR2 Energy (kcal/kg): 4,100, Protein (\%):19, Fat (\%):3 - 8, Calcium (\%):0.9 - 1.1, Phosphorus (\%): 0.6 - 0.9. (Br 1 for 0-4 weeks and $\mathrm{Br} 2$ for $4-12$ weeks), using the ND vaccine on DOC, and the drugs used are vitamin $\mathrm{C}$, tetra-chlor.

\section{Methods}

The experimental or direct observation method is used in this study. Body weight, body weight gain, and body measurements are all analysis. The 315 eggs from the first generation elders of Kampung Super chickens and Bangkok chickens used in this study had an average weight of 59.21 Kampung Super eggs and 55.42 Bangkok chickens. The collected eggs are marked with a marker on the blunt side and the letters of the alphabet $(\mathrm{A}, \mathrm{B}, \mathrm{C})$ on the other to facilitate the process of turning the eggs during incubation, then the eggs are weighed and placed in a manual incubator with a temperature of $35-39^{\circ} \mathrm{C}$ and a humidity of $50-60{ }^{\circ} \mathrm{C}$ for \pm 21 days. Chickens are kept from hatching until they are three months old. How to maintain chickens in colony cages by feeding and drinking continuously (ad libitum). Each strain is housed in its cage, the cage used is $4 \times 3 \times 1.8 \mathrm{~m}$ for enlargement cages containing 100 birds and $2 \times 1.5 \times 1.8 \mathrm{~m}$ for contains 7 brooders consisting of 1 male and 6 female equipped with feed, drinking places, and lighting. Every week the body weight was measured, and every month the body weight was measured.

The variables observed in this study were: Bodyweight at DOC, 4, 8, and 12 Weeks of age, body weight gain, and body measurements. Beak length (BL), beak width (BW), head length (HL), head circumference $(\mathrm{HC})$, head height $(\mathrm{HH})$, neck length $(\mathrm{NL})$, neck circumference $(\mathrm{NC})$, wing length (WL), back length (BL), back height (BH), long lower body (LBL), chest length (CL), chest width $(\mathrm{CW})$, chestcircumference (CC), shank length (SL), shank circumference (SC), tibia length (TL), tibiacircumference (TC), third finger length (TFL), pubic bone distance (PBD) (Figure 1). and selection response.

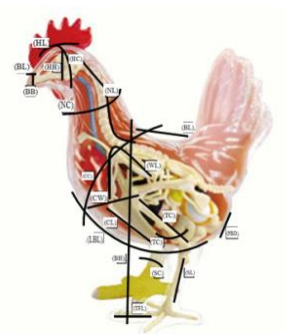

Figure 1. Observed Variables

\section{Data Analysis \\ t-test independent}

The $\mathrm{t}$ test independent is the average difference test used to see the difference; Hatching weight (DOC), body weight at a certain age, body weight gain and body measurements between Kampung Super and Bangkok chicken lines [5].

Information :

$\mathrm{t}=$ value $\mathrm{t}$ count; $(X) \mathrm{i}=$ sample mean in the first group; $X 2$ = sample mean in the second group; $X \_j 1=$ the value of the $J$-th observation in the first group; $X \_j 2=$ the value of the J-th observation in the second group; $\mathrm{n} 1=$ number of samples in the first group; and $\mathrm{n} 2=$ number of samples in the second group.

Decision Rules:

Accept Ho if $\mathrm{t}$-count $\mathrm{t}$-table

Accept $\mathrm{H} 1$ if $\mathrm{t}$-count $>\mathrm{t}$-table

Vector mean values of body sizes of Kampung Super chickens and Bangkok chickens, including; beak length (BL), beak width (BW), head length (HL), head circumference $(\mathrm{HC})$, head height $(\mathrm{HH})$, neck circumference (NC), wing length $(\mathrm{WL})$, back length (BL), back height $(\mathrm{BH})$, lower body length (LBL), chest length $(\mathrm{CL})$, chest width $(\mathrm{CW})$, chest circumference (CC), shank length (SL), shank circumference (SL), tibia length (TL), tibial circumference (TC), third finger length (TFL), pubic bone distance (PBD), was tested using the T2Hotelling statistical test [5]. The test is carried out by formulating the following hypotheses: 
Ho : $\mathrm{U} 1=\mathrm{U} 2$ means that the vector average value of the first group of livestock is the same as that of the second group of livestock.

H1 : U1 U2 means that the two mean value vectors are different

[5] stated that the test of the above hypothesis was carried out using the T2-Hotelling statistical test. T2-Hotelling is formulated as follows:

$$
\mathrm{T}^{2}=\frac{\mathrm{n}_{1} \mathrm{n}_{2}}{\mathrm{n}_{1}+\mathrm{n}_{2}}\left(\overline{\mathrm{X}_{1}}-\overline{\mathrm{X}_{2}}\right) \mathrm{S}_{\mathrm{G}}^{-1}\left(\overline{\mathrm{X}_{1}}-\overline{\mathrm{X}_{2}}\right)
$$

Next

$$
\mathrm{F}=\frac{\mathrm{n}_{1}+\mathrm{n}_{2}-\mathrm{p}-1}{\left(\mathrm{n}_{1}+\mathrm{n}_{2}-2\right) \mathrm{p}} \mathrm{T}^{2}
$$

will be distributed $\mathrm{F}$ with degrees of freedom $\mathrm{V} 1=\mathrm{p}$ and $\mathrm{V} 2=\mathrm{n} 1+\mathrm{n} 2-\mathrm{p}-1$

Information:

$\mathrm{T} 2=\mathrm{T} 2$-Hotelling statistic value; $\mathrm{F}=$ calculated value for $\mathrm{T} 2$-Hotelling; $\mathrm{n} 1=$ the number of observational data in the first group of livestock; $\mathrm{n} 2$ = the number of observational data in the second group of livestock; $\mathrm{X} 1$ = vector mean value of random variable in the first group of cattle; $\mathrm{X} 2=$ vector mean value of random variable in the second group of livestock; SG-1 = the inverse of the composite diversification matrix (the inverse of the SG matrix); $P=$ number of measuring variables.

Two groups are declared equal if $\mathrm{T} 2$

$$
\mathrm{T}^{2} \leq \frac{\left(\mathrm{n}_{1}+\mathrm{n}_{2}-2\right) \mathrm{p}}{\mathrm{n}_{1}+\mathrm{n}_{2}-\mathrm{p}-1} \mathrm{~F} \alpha ; \mathrm{v}_{1}, \mathrm{v}_{2}
$$

Stated different if $\mathrm{T} 2$

$$
\mathrm{T}^{2} \geq \frac{\left(\mathrm{n}_{1}+\mathrm{n}_{2}-2\right) \mathrm{p}}{\mathrm{n}_{1}+\mathrm{n}_{2}-\mathrm{p}-1} \mathrm{~F} \alpha ; \mathrm{v}_{1}, \mathrm{v}_{2}
$$

If the T2-Hotelling test showed significant results $(\mathrm{P}<0.05)$, then the data processing for each group of livestock was continued with Main Component Analysis.

\section{Principal Component Analysis}

Principal component analysis to determine size and shape characteristics of Kampung
Super chickens and Bangkok chickens. The goal is to find several coherent variables in the subgroups, which are relatively independent of the others. Differences in body size and shape observed were analysed based on Principal Componen Analyzis (PCA). The equations of size and shape are derived from the covariance matrix. The mathematical model used for this analysis [5] is as follows:

$$
Y j=a_{1 j} X_{1}+a_{2 j} X_{2}+a_{3 j} X_{3}+\cdots+a_{7 j} X_{7}
$$

Information: $\mathrm{Yj}=\mathrm{jth}$ principal component $(\mathrm{j}=1$, $2 ; 1=$ size, 2 = shape ); $X 1,2,3 \ldots=$ variable to $1,2,3 \ldots .7 ;$ aij, $2 \mathrm{j}, 3 \mathrm{j}, . .=$ ith variable eigenvector $(1,2,3, \ldots .7)$ and $j$ th principal component.

\section{Selection response}

$$
\begin{array}{ll}
R & =\mathrm{G} 1-\mathrm{G} 0 \\
\mathrm{H}^{2} & =\mathrm{G} 1 / \mathrm{DS} \\
\mathrm{DS} & =\mathrm{G} 0 \text { Selection - initial population G0 }
\end{array}
$$

Information: $\mathrm{R}=$ Selection response; $\mathrm{H}^{2}=$ Heritability; DS = Selection dependent; G1 = First generation; G0 = Generation zero / Elder.

\section{RESULTS}

\section{Average body weight of Kampung Super Chickens and Bangkok chickens}

The average body weight of G1 Kampung Super and Bangkok chickens aged DOC, 4 week, 8 weeks, and 12 weeks is presented in Table 1 and Figure 2. The results of the analysis of the average difference test showed that the body weights of G1 Kampung Super Chickens were significantly different higher $(\mathrm{P}<0.05)$ than $\mathrm{G} 1$ Bangkok chickens.

\section{G1 Kampung Super and Bangkok chicken body weight gain}

Body weight gain of G1 Kampung Super and Bangkok chickens aged DOC-4 week, 4-8 weeks, and 8-12 weeks are presented in Table 2 and Figure 3. The results average difference test showed that the body weight gain of DOC- 4 week, 4-8 weeks, and 8-12 weeks of G1

Table 1. Average Body Weight of G1 Kampung Super Chickens and Bangkok Chickens

\begin{tabular}{lcc}
\hline \multicolumn{1}{c}{ Age $(\mathrm{g})$} & Kampung Super & Bangkok \\
\hline DOC & $42.41 \pm 2.76^{\mathrm{a}}$ & $38.15 \pm 1.48^{\mathrm{b}}$ \\
4 weeks & $414.08 \pm 49.04^{\mathrm{a}}$ & $372.36 \pm 16.24^{\mathrm{b}}$ \\
8 weeks & $838.03 \pm 72.30^{\mathrm{a}}$ & $787.92 \pm 26.19^{\mathrm{b}}$ \\
12 weeks & $1326.31 \pm 128.07^{\mathrm{a}}$ & $1244.81 \pm 81.54^{\mathrm{b}}$ \\
\hline
\end{tabular}

Different superscripts in the same line for each chicken strain is mean real different $(\mathrm{P}<0.05)$ 


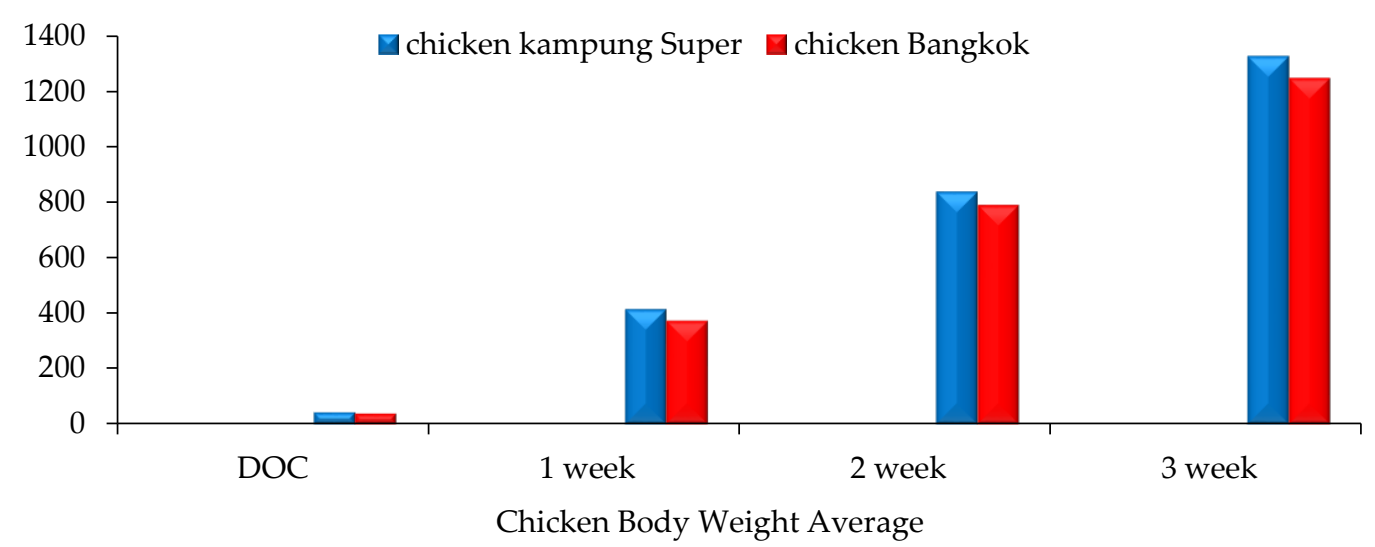

Figure 2. Shows a comparison of the average body weights of G1 Kampung Super and Bangkok chickens

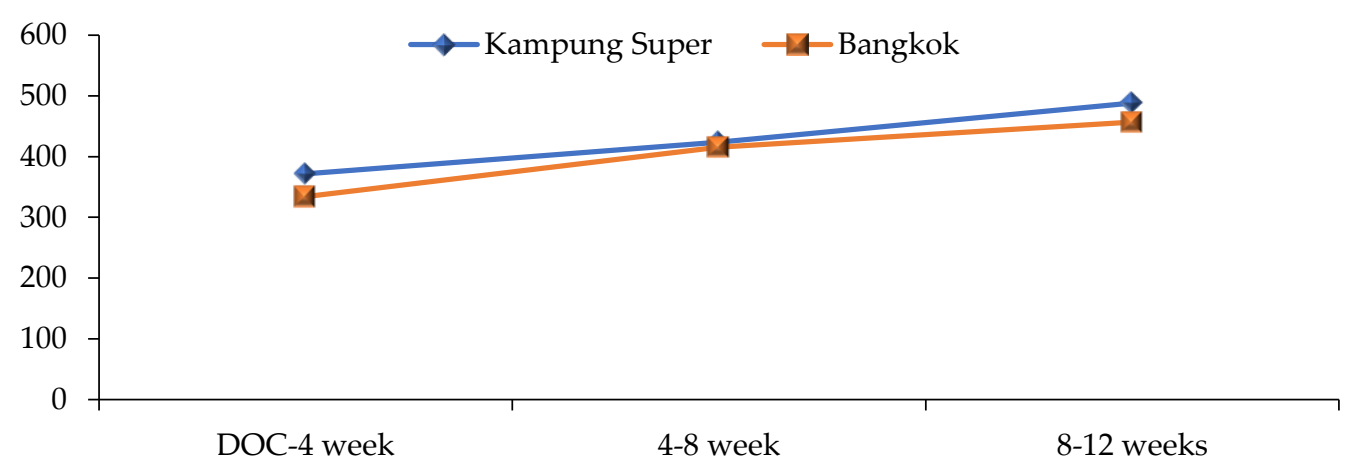

Chicken Body Weight Gain average

Figure 3. Average Body weight gain graphs of G1 Kampung Super and Bangkok chickens

Kampung Super chickens was significantly different $(\mathrm{P}<0.05)$ higher than $\mathrm{G} 1$ Bangkok chickens.

The results of the analysis of differences in the average body weight gain of G1 Kampung Super and Bangkok chickens from 8- 12 weeks of age were real different $(\mathrm{P}<0.05)$ higher than 4-8 weeks of age, body weight gain of 4-8 weeks of age was real different $(\mathrm{P}<0.05)$ was higher than the weight gain of DOC-4 week.

\section{Average body measurements of Kampung Super Chickens and Bangkok Chickens}

The average body measurements of G1 Kampung Super and Bangkok chickens at the age of 12 weeks are can be seen in Table 3.
Table 3. shows that the results of the average difference in body sizes of G1 Kampung Super chickens were significantly different higher $(\mathrm{P}<0.05)$ than $\mathrm{G} 1$ Bangkok chickens.

\section{Test $\mathbf{T}^{2}$-hotelling}

Table 4 shows the results of the $\mathrm{T}^{2}$ Hotelling analysis on body sizes of G1 Kampung Super and Bangkok chickens, male, female, and combined. Table 4. shows that the statistical test $T^{2}$-Hotelling on body measurements G1 Super chicken significantly different higher $(\mathrm{P}<0.01)$ than $\mathrm{G} 1$ Bangkok chickens.

\section{G1 Kampung Super and Bangkok chickens have similar body sizes and shapes}

Table 2. Average body weight gain of G1 Kampung Super chickens and Bangkok chickens

\begin{tabular}{lccc}
\hline \multicolumn{1}{c}{ Type } & DOC-4 weeks & $4-8$ weeks & $8-12$ weeks \\
\hline Kampung Super & $371.67 \pm 46,59 \mathrm{c}$ A & $423.95 \pm 37.977^{\mathrm{bA}}$ & $488.28 \pm 73.30^{\mathrm{aA}}$ \\
Bangkok & $334.21 \pm 14,96^{\mathrm{cB}}$ & $415.57 \pm 18.47^{\mathrm{bB}}$ & $456.88 \pm 67.85^{\mathrm{aB}}$ \\
\hline
\end{tabular}

Different uppercase superscripts in the same column for each chicken strain were significantly. Different $(\mathrm{P}<0.05)$. Different lowercase superscripts in the same line are significantly different $(\mathrm{P}<0.05)$. $\mathrm{T}$ test Independet. Mean \pm Standar Deviasi 
Table 5 shows the size and shape equations, amount diversity (AD), and eigenvalues $(\lambda)$ of G1 Kampung Super and Bangkok chickens. PCA is used to determine the size and shape characteristics of G1 Kampung Super and Bangkok chickens. Table 5. shows that the total diversity of the main components of the 1st Kampung Super and Bangkok chickens is $71.8 \%$ and $78 \%$, with Eigenvalues of 14.37, and 15.60. The amount diversity of the 2nd maincomponent which is equivalent to the shape of Kampung Super chicken and Bangkok chicken is $6 \%$ and $6.5 \%$ with eigenvalues of 1.20 and 1.31 . This percentage is the largest proportion of variance among the main components obtained.

The highest component variable in the body size equation of G1 Kampung Super and Bangkok chickens is Chest Circumference (CC). The highest main component variable obtained in the body shape characterizing equation of G1 Kampung Super chicken is Wing Length (WL), and
G1 Bangkok chicken is Lower Body Length (LBL).

\section{Selection response}

The average response to body weight selection at 12 weeks of age G1 Kampung Super and Bangkok chickens is presented in Table 6. shows that the selection response (R) of average body weight at the age of 12 weeks between parents and first-generation (G1) Kampung Super chickens and Bangkok chickens is 7.8 and 8.40 . The results of the estimation of heritability values for each chicken strain (G1 Kampung Super and Bangkok chicken) are 0.33 and 0.41 .

\section{DISCUSSIONS}

The average body weight of Kampung Super chickens from the age of DOC, 4, 8, and 12 weeks from this study was higher than several other studies. The bodyweight of Kampung Super chickens aged DOC is $42 \mathrm{~g}$, [6], the body weight of Kampung Super

Table 3. Average body measurements of G1 Kampung Super chickens and Bangkok

\begin{tabular}{|c|c|c|}
\hline Body measurements & Kampung Super & Bangkok \\
\hline $\mathrm{BL}(\mathrm{mm})$ & $46.51 \pm 5.06^{a}$ & $40.80 \pm 3.76^{b}$ \\
\hline $\mathrm{BW}(\mathrm{mm})$ & $47.18 \pm 3.79^{a}$ & $42.77 \pm 3.15^{b}$ \\
\hline $\mathrm{HL}(\mathrm{mm})$ & $8.67 \pm 0.77 \mathrm{a}$ & $6.70 \pm 1.18^{\mathrm{b}}$ \\
\hline $\mathrm{HC}(\mathrm{mm})$ & $39.11 \pm 4.59$ a & $34.30 \pm 4.64^{\mathrm{b}}$ \\
\hline $\mathrm{HH}(\mathrm{mm})$ & $116.49 \pm 6.61^{a}$ & $122.50 \pm 8.33^{\mathrm{b}}$ \\
\hline NL (mm) & $147.46 \pm 12.64^{a}$ & $137.59 \pm 16.91^{\mathrm{b}}$ \\
\hline $\mathrm{NC}(\mathrm{mm})$ & $101.78 \pm 8.47^{a}$ & $95.54 \pm 9.56^{\mathrm{b}}$ \\
\hline $\mathrm{WL}(\mathrm{mm})$ & $218.48 \pm 19.63^{a}$ & $201.65 \pm 19.63^{b}$ \\
\hline $\mathrm{BL}(\mathrm{mm})$ & $303.77 \pm 13.40^{a}$ & $290.53 \pm 12.07^{b}$ \\
\hline $\mathrm{BH}(\mathrm{mm})$ & $312.12 \pm 15.70^{a}$ & $299.51 \pm 16.81^{b}$ \\
\hline LBL (mm) & $343.40 \pm 22.01^{a}$ & $328.01 \pm 23.02^{\mathrm{b}}$ \\
\hline CL (mm) & $141.67 \pm 9.69^{a}$ & $136.55 \pm 8.08^{\mathrm{b}}$ \\
\hline $\mathrm{CW}(\mathrm{mm})$ & $71.84 \pm 5.99 a$ & $66.22 \pm 4.25^{\mathrm{b}}$ \\
\hline $\mathrm{CC}(\mathrm{mm})$ & $336.92 \pm 23.96^{\mathrm{a}}$ & $320.23 \pm 20.31^{b}$ \\
\hline SL (mm) & $91.28 \pm 6.98^{a}$ & $87.12 \pm 8.91^{b}$ \\
\hline $\mathrm{SC}(\mathrm{mm})$ & $54.21 \pm 5.74^{\mathrm{a}}$ & $48.16 \pm 4.92^{\mathrm{b}}$ \\
\hline TL (mm) & $145.91 \pm 10.14^{\mathrm{a}}$ & $139.80 \pm 9.14^{\mathrm{b}}$ \\
\hline $\mathrm{TC}(\mathrm{mm})$ & $117.00 \pm 10.58^{a}$ & $111.07 \pm 9.82^{\mathrm{b}}$ \\
\hline TFL (mm) & $72.74 \pm 5.87 a$ & $68.94 \pm 5.15^{b}$ \\
\hline PBD (mm) & $15.49 \pm 1.10^{a}$ & $14.32 \pm 1.22^{\mathrm{b}}$ \\
\hline
\end{tabular}

Different superscripts in the same line for each type of chicken mean significantly different $(\mathrm{P}<0.05)$, Beak Length (BL), Beak Width (BW), Head Length (HL), Head Circumference (HC), Head Height (HH), Neck Length (NL), Neck Circumference (NC), Wing Length (WL), Back Length (BL), Back Height (BH), Lower Body Length (LBL), Chest Length (CL), Chest Width (CW), Chest Circumference (CC), Shank Length (SL), Shank Circumference (SL), Tibia Length (TL), Tibial Circumference (TC), Third Finger Length (TFL), Pubic Bone Distance (PBD). Mean \pm Standar Deviasi 
Table 4. shows the results of $\mathrm{T}^{2}$-Hotelling tests performed on G1 Kampung Super and Bangkok chickens

\begin{tabular}{lcccc}
\hline \multicolumn{1}{c}{ Body Measurements } & Statistics T2-Hotteling & Value F & Value P & Conclusion \\
\hline $\begin{array}{l}\text { Kampung Super } \\
\text { Bangkok }\end{array}$ & 132779.88 & 6312.80 & 0,01 & $* *$ \\
\hline S = Super and B = Bangkok. ${ }^{* *}$ = Significantly Different $(\mathrm{P}<0.01)$ & & & \\
\end{tabular}

Table 5. Similarities in body size and shape of G1 Kampung Super chickens and Bangkok chickens

\begin{tabular}{|c|c|c|c|c|}
\hline Type & & Equation & $\mathrm{TD}(\%)$ & $\Lambda$ \\
\hline \multirow[t]{2}{*}{$\begin{array}{l}\text { Kampung } \\
\text { Super }\end{array}$} & body size & $\begin{aligned}= & 0.234 \mathrm{BL}+0.234 \mathrm{BW}+0.212 \mathrm{HL}+0.223 \mathrm{HC}+0.217 \mathrm{HH}+ \\
& 0.203 \mathrm{NL}+0.234 \mathrm{NC}+0.160 \mathrm{WL}+0.216 \mathrm{BL}+0.224 \mathrm{BH}+ \\
& 0.238 \mathrm{LBL}+0.233 \mathrm{CL}+0.233 \mathrm{CW}+0.241 \mathrm{CC}+0.220 \mathrm{SL}+ \\
& 0.193 \mathrm{SC}+0.238 \mathrm{TL}+0.238 \mathrm{TC}+0.236 \mathrm{TFL}-0.227 \mathrm{PBD}\end{aligned}$ & 7.8 & 14.37 \\
\hline & Body shape & $\begin{aligned}= & 0.348 \mathrm{BL}+0.178 \mathrm{BW}-0.002 \mathrm{HL}+0.345 \mathrm{HC}-0.255 \mathrm{HH}- \\
& 0.190 \mathrm{NL}-0.122 \mathrm{NC}+0.383 \mathrm{WL}-0.168 \mathrm{BL}-0.289 \mathrm{BH}- \\
& 0.203 \mathrm{LBL}-0.198 \mathrm{CL}-0.123 \mathrm{CW}-0.174 \mathrm{CC}-0.169 \mathrm{SL}- \\
& 0.293 \mathrm{SC}-0.140 \mathrm{TL}+0.022 \mathrm{TC}+0.039 \mathrm{TFL}-0.302 \mathrm{PBD}\end{aligned}$ & 6 & 1.20 \\
\hline \multirow[t]{2}{*}{ Bangkok } & body size & $\begin{aligned}= & 0.214 \mathrm{BL}+0.228 \mathrm{BW}+0.232 \mathrm{HL}-0.226 \mathrm{HC}+0.228 \mathrm{HH}+ \\
& 0.223 \mathrm{NL}+0.230 \mathrm{NC}+0.226 \mathrm{WL}+0.222 \mathrm{BL}+0.201 \mathrm{BH}+ \\
& 0.222 \mathrm{LBL}+0.227 \mathrm{CL}+0.227 \mathrm{CW}+0.233 \mathrm{CC}+0.231 \mathrm{SL}+ \\
& 0.228 \mathrm{SC}+0.213 \mathrm{TL}+0.214 \mathrm{TC}+0.227 \mathrm{TFL}-0.217 \mathrm{PBD}\end{aligned}$ & 78 & 15.60 \\
\hline & Body shape & $\begin{aligned}= & -0.422 \mathrm{BL}+0.261 \mathrm{BW}-0.265 \mathrm{HL}-0.284 \mathrm{HC}+0.121 \mathrm{HH}- \\
& 0.033 \mathrm{NL}+0.49 \mathrm{NC}+0.127 \mathrm{WL}+0.227 \mathrm{BL}+0.361 \mathrm{BH}+ \\
& 0.206 \mathrm{LBL}+0.056 \mathrm{CL}-0.158 \mathrm{CW}+0.176 \mathrm{CC}-0.010 \mathrm{SL}- \\
& 0.036 \mathrm{SL}+0.250 \mathrm{TL}+0.306 \mathrm{TC}-0.013 \mathrm{TFL}+0.357 \mathrm{PBD}\end{aligned}$ & 6,5 & 1.31 \\
\hline
\end{tabular}

Beak Length (BL), Beak Width (BW), Head Length (HL), Head Circumference (HC), Head Height (HH), Neck Length (NL), Neck Circumference (NC), Wing Length (WL), Back Length (BL), Back Height (BH), Lower Body Length (LBL), Chest Length (CL), Chest Width (CW), Chest Circumference (CC), Shank Length (SL), Shank Circumference (SC), Tibia Length (TL), Tibial Circumference (TC), Third Finger Length (TFL), Pubic Bone Distance (PBD)

chickens aged 4 weeks is $276.94 \mathrm{~g}$ - $318.56 \mathrm{~g}$ [7], the bodyweight of Kampung Super chickens aged 8 weeks is $837.97 \mathrm{~g}$, [2] and G1 Kampung Super aged 12 weeks is $612 \mathrm{~g}-780,39 \mathrm{~g}$ [3]. The average body weight of G1 Bangkok chickens from DOC, 4, 8, and 12 weeks ages was higher than several other studies. The bodyweight of G1 Bangkok Chicken aged DOC was $37.63 \mathrm{~g}$, [8], the bodyweight of G1 Bangkok Chicken aged 4 weeks was $250.74 \mathrm{~g}$, 8 weeks is $690,05 \mathrm{~g}$ [9] and 12 weeks $1044 \mathrm{~g}$ [10]. The results of this study are better than some previous studies. This difference is thought to be due to genetic and environmental influences. Bodyweight is influenced by genetics (lines), environment, maintenance management, quality, and quantity of feed consumed [11].

The results of the average difference test analysis showed that the body weights of DOC, 4, 8, and 12 weeks G1 Kampung Super Chickens were significantly different higher $(\mathrm{P}<0.05)$ than G1 Bangkok chickens. This shows that the average body weight of G1 Kampung Super chickens is higher than G1 Bangkok chickens. This difference is thought to be due to the influence of genetic factors. This is by the opinion [2] which states that differences in body weight of chickens receiving the same environmental and feed treatment are influenced by genetic factors. [11] stated that one of the factors that can influence chicken weight is the genetics of each chicken strain.

The average body weight gain of G1 Kampung Super chickens from the age of DOC-4 weeks, 4-8 weeks, and 8-12 weeks of this study were higher than the previous study [12] which stated that the body weight gain of DOC-4 weeks, 4-8 weeks and 8-12 weeks Kampung Super chicken were $202.00 \mathrm{~g}, 280.3 \mathrm{~g}$, and $416.1 \mathrm{~g}$. The average body weight gain of G1 Bangkok chickens from the age of DOC-4 weeks, $4-8$ weeks, and 
Table 6. Responses to body weight selection at 12 weeks of age G1 Kampung Super and Bangkok chickens

\begin{tabular}{lcccc}
\hline \multirow{2}{*}{ Type } & \multicolumn{4}{c}{ 12 weeks hold body weight } \\
\cline { 2 - 5 } & $\begin{array}{c}\text { Differential } \\
\text { selection }\end{array}$ & saplings & $\begin{array}{c}\text { Selection response } \\
(\mathrm{g})\end{array}$ & $\begin{array}{c}\text { Heritability } \\
\left(\mathrm{H}^{2}\right)\end{array}$ \\
\hline Kampung Super $(\mathrm{g})$ & 23.49 & 1326.31 & 7.80 & 0.33 \\
Bangkok $(\mathrm{g})$ & 20.62 & 1244.81 & 8.40 & 0.41 \\
\hline
\end{tabular}

8-12 weeks were higher than some other studies. The body weight gain of G1 Bangkok Chickens aged DOC-4 week is $215.88 \mathrm{~g}$ and 4-8 weeks is $439.12 \mathrm{~g}$ [9] This research is better than some previous studies. This difference is thought to be due to genetic, environmental, and livestock rearing systems. This is by the opinion $[13 ; 14]$ which states that the growth rate of chickens is influenced by the type of chicken, chicken strain, sex, ration consumption, environmental conditions, temperature, and disease.

The average body weight gain of G1 Kampung Super chickens is better than G1 Bangkok chickens. The difference in body weight gain is thought to be due to genetic differences in each chicken strain. This is by the opinion [2] which states that the difference in the body weight gain of chickens is due to the influence of genetic factors. The results of this study indicate that the highest body weight gain of G1 Kampung Super and Bangkok chickens is achieved at the age of 8-12 weeks, [15] states that the body weight gain of chickens has increased at a grower age. The results of this study were different from [9] which stated that the highest body weight gain of Bangkok chickens was achieved at the age of 4-8 weeks. This difference is thought to be due to genetic differences and environmental conditions including maintenance management [16;17].

G1 Kampung Super chickens have larger body sizes so they have higher performance than G1 Bangkok chickens. [18] stated that the body size of livestock may differ from one another which may be caused by genetic, location of origin, as well as the system of rearing and mating applied.

The difference in body sizes of livestock is thought to be due to the genetic influence of livestock because environmental conditions and treatment at the time of the study were the same, so the differences in body sizes of G1
Kampung Super and Bangkok chickens were caused by the genetic diversity of livestock. This is by the opinion [4] which states that diversity in livestock can be sourced from genetic diversity, where genetic diversity can be caused by additive genes, most genes, and epistasis genes.

Differences in body sizes of livestock are thought to be caused by differences in the capacity of the body frame structure which is influenced by genetic factors. This is by the opinion [19] which states that genetic and environmental factors also have a close relationship so that they can affect the body sizes of livestock. Based on the test T2Hotelling can be stated that the G1 Super chicken has a larger body size compared to G1 Bangkok chicken. The difference between the two strains shows that there are differences in body skeleton which are mostly influenced by genetics, because the environment has been tried to be the same, such as feed and maintenance in the same environment. [20] stated that differences in body size and shape in livestock breeds may be caused by differences in genetic factors.

Chest circumference (CC) can be used as a determinant of body size in G1 Kampung Super chickens and Bangkok chickens because it has the largest contribution to the body size equation. This study is similar to the results of research [21] which stated that the body size of local East Kalimantan chickens was chest circumference. According to [17] that in principal component analysis, phenotypic parameters can be used to determine morphometric parameters that indicate national markers and are referred to as nationdistinguishing variables.

The highest main component variable obtained in the equation to characterize the body shape of G1 Kampung Super chickens is Wing Length (WL), and G1 Bangkok chickens is Lower Body Length 
(LBL). The results of this study differ from research [2] which states that the body size indicator in Kampung Super chickens is the length of the tibia, while the body shape is the chest width. This difference is thought to be caused by differences in genetic, environmental, and maintenance factors in each line. According to [2] that the body shape of chickens is strongly influenced by genetics, while body size is not only influenced by genetics, it is also influenced by the environment or the topography of the area, the purpose of raising and caring for chickens. According to [22] thet identification is done by finding the determinants of each type of local chicken based on size and shape which are calculated using the Main Component Analysis (AKU) statistical method.

The results of this selection response G1 Kampung Super and Bangkok chickens study were higher than research [23] which stated that the selection response in ducks was 5.66. The selection response that is still positive indicates that the chicken line has not lost its genetic and phenotypic diversity. This is the same as the opinion of [24] which states that a positive selection response from all lines indicates that the chicken population has not lost its genetic diversity and phenotypic variety, which is marked by a decrease in the selection response to zero.

The results of the estimation of the heritability value of this study were higher than the study [23] which stated that the heritability value of ducks ranged from $0.37-0.48$. This shows that there is an increase or response to the selection of genetic quality of livestock in the form of phenotypic and genetic advantages of livestock selected as elders in the next generation compared to the initial population average. Selection response or increase in livestock genetic quality $(\Delta G)$ in the form of genetic superiority of livestock selected as parents in the next generation compared to the initial population average. Several ways to maximize genetic progress include: 1) maximizing the selection differential in the form of performance differences between selected livestock and their populations or maximizing the value of selection intensity by tightening the proportion of selected livestock, 2) increasing heritability values, by minimizing environmental diversity or standardizing environmental management and 3) maintain the genetic diversity of selected traits [25].

\section{CONCLUSIONS}

Based on the findings and discussions, it is possible to conclude that the performance of G Kampung Super chicken, including body weight, weight gain, and body measurements, is superior to that of G1 Bangkok chicken at the DOC, 4 week, 8 weeks, and 12 weeks. The greatest body weight gain inG1 Super and Bangkok chickens occurred between the ages of 8-12 weeks. Size markers in G1 Kampung Super and Bangkok chickens are Chest Circumference (CC), while shape characteristics in Kampung Super chickens are Wing Length (LW) and Bangkok chickens are Lower Body Length (LBL), and the selection response in G1 Kampung Super chickens is lower than the selection response in G1 Bangkok chickens. The heritability value of Kampung Super G1 chicken and Bangkok chicken was high. The high value of the heritability of a trait indicates a high correlation of phenotypic variance and genetic variance.

\section{CONFLICT OF INTEREST}

The authors declares that we does not have a conflict of interest.

\section{ACKNOWLEDGMENTS}

Thank you for your interest in the Animal Science Study Program at Jambi University's Faculty of Animal Husbandry.

\section{REFERENCES}

1. Ashar, M. A. Pagala, dan T. Saili. 2016. Karakteristik fenotip kualitatif ayam Kampung Super. Jurnal Ilmiah Peternakan Halu Oleo. 1(1):1-9.

2. Putri, A. B. S. R. N., Gushairiyanto, dan Depison. 2020. Bobot badan dan karakteristik morfometrik beberapa galur ayam lokal. Jurnal Ilmu dan 
Teknologi Peternakan Tropis. 7:3256-263. Doi: 10.33772/jitro.v7i3.12150

3. Pakaya, S. A., S. Zainudi, dan S. Dako. 2019. Performa ayam Kampung Super yang diberi level penambahan tepung kulit kakao (Theobroma Cacao, L.) fermentasi dalam ransum. Jambura Journal of Animal Science. 1(1):40-45.

4. Lukmanudin, M., C. Sumantri, and S. Darwati. 2018. Ukuran tubuh ayam lokal silangan IPB D-1 generasi kelima umur 2 sampai 12 minggu. Jurnal Ilmu Produksi dan Teknologi Hasil Peternakan. 6(3):113-120.

5. Gaspersz, V. 2006. Teknik analisis dalam penelitian percobaan. Tarsito, Bandung.

6. Anggraini, A. D., W. Widodo, I. D. Rahayu, dan A. Supetanto. 2019. Efektivitas penambahan tepung temulawak dalam ransum sebagai upaya peningkatan produktivitas ayam Kampung Super. Jurnal Sain Peternakan Indonesia. 14(2):222-227. Doi: 10.31186/jspi.id.14.2.2 22-227

7. Munira, S., L. O. Naviu, dan M. Tasse. 2016. Performans ayam Kampung Super pada pakan yang disubtitusi dedak padi fermentasi dengan fermentor berbeda. Jurnal Ilmu dan Teknologi Peternakan Tropis. 3(2)21-29. Doi: 10.33772/jitro.v3i2. 1683

8. Saragih, E. S. G. 2020. Identifikasi karakteristik kuantitatif ayam Bangkok dan ayam Merawang. Universitas Jambi Press, Jambi.

9. Pagala, M. A., L. O. Nafihu, dan S. Maharani. 2019. Keragaan ukuran dimensi tubuh hasil persilangan ayam Petelur dan Bangkok pada fase starter. Jurnal Ilmu dan Teknologi Peternakan Tropis. 6:2251-258. Doi: 10.33772/jitro.v6i2.7140

10. Fahrudin, A., W. Tanwiriah, H. Indrijani. Konsumsi ransum, pertambahan bobot badan dan konversi ransum ayam lokal di Jimmy's farm Cipanas Kabupaten Cianjur. Student e-Journals. 6(1): 1-8.

11. Wijayanti, R. P. 2013. Pengaruh suhu kandang yang berbeda terhadap performans ayam pedaging periode starter. Repository Jurnal Mahasiswa. Juli: $1-6$.
12. Kholik, A., H. Indrijani, dan W. Tanwiriah. 2019. Model kurva pertumbuhan ayam Super Garut yang diberi tepung pask bumi (Euricoma longifolia Jack) dalam ransum. Jurnal Ilmu Ternak. 19:169-77. Doi: 10.24198/jit.v19i1.20257

13. Risnajati, D. 2014. Pengaruh jumlah ayam per induk buatan terhadap performan ayam strain isa brown periode starter. Sains Peternakan. 12:110-14. Doi: 10.20961/sainspet.v12i1.4866

14. Subekti, K dan F. Arlina. 2011. Karakteristik genetik eksternal ayam Kampung di Kecamatan Sungai Pagu Kabupaten Solok Selatan. Jurnal Ilmiah Ilmu-ilmu Peternakan. 14:274-86. Doi: 10.22437/jiiip.v14i2.867

15. Urfa, S., H. Indijani, and W. Tanwiriah. 2017. Model kurva pertumbuhan ayam Kampung Unggul Balitnak (KUB) umur 012 minggu. Jurnal Ilmu Ternak. 17:159-66. Doi: 10.24198/jit.v17i1.14863

16. North, M. O. and D. D. Bell. 1990. Commercial Chicken Production Manual. Fourth Edition. Van Nostrand Rain Hold, New York.

17. Mariandayani, H. N., D. Duryadi. S. Sulandari, dan C. Sumantri. 2013. Keragaman fenotipik dan pendugaan jarak genetik pada ayam lokal dan ayam Broiler menggunakan analisis morfologi. Jurnal Veteriner.14(4):475-484.

18. Hikmawaty, A. Gunawan, R. R. Noor, dan Jakaria. 2014. Identifikasi ukuran tubuh dan bentuk tubuh sapi Bali di beberapa pusat pembibitan melalui pendekatan analisis komponen utama. Jurnal Ilmu Produksi dan Teknologi Hasil Peternakan. 02:231-237.

19. Kurnianto, E., S. Sutopo, E. Purbowati, E. T. Setiatin, D. Samsudewa, and T. Permatasari. 2013. Multivariate analysis of morfphological traits of local goats in Central Java-Indonesia. Iran. J. App. Anim. Sci. 3(2):361-367.

20. Mahmudi, R. Priyanto, and Jakaria. 2019. Karakteristik morfometrik sapi Aceh, sapi PO dan sapi Bali berdasarkan analisis komponen utama (AKU). Jurnal Ilmu Produksi dan Teknologi Hasil Peternakan. 7:135-40. 
21. Ramatullah, S. N., Z. Efendi, H. Mayulu, F. Ardhani, and A. Sulaiman. 2018. Perbandingan morfometrik ayam lokal Kalimantan Timur berdasarkan pendekatan analisis diskriminan. Peternakan Tropika. 6:3817-828.

22. Candrawati, V. Y. 2007. Studi ukuran dan bentuk tubuh ayam Kampung, ayam Sentul dan ayam Wareng Tangerang. Skripsi. Fakultas Peternakan, Institut Pertanian Bogor, Bogor.

23. Abrianto, I. M. U. L. Hakim, V. M. A. Nurgiartiningsih. 2017. Pendugaan heritabilitas rill (realized heritability) dan kemajuan genetik produksi telur itik Mojosari. Jurnal Ilmu-ilmu Peternakan. 27:74-80.

24. Hardjosubroto, W. 1994. Aplikasi pemuliabiakan ternak di lapangan. PT Grasindo, Jakarta.

25. Warwick, E., J. J. M. Astuti, dan W. Hardjosubroto. 1983. Pemuliaan ternak. Edisi ke-1. Gadjah Mada University Press, Yogyakarta. 